\title{
GEOFYZIKÁLNÍ MAPOVÁNÍ KRASOVÝCH STRUKTUR METODOU MULTIELEKTRODOVÉHO ODPOROVÉHO PROFILOVÁNÍ: JESKYNĚ ZA HÁJOVNOU, JAVOŘÍČSKÝ KRAS
}

\author{
Geophysical mapping of karst structures using multielectrode resistivity surveys; example \\ from "Za hájovnou" Cave, Javořícko Karst
}

\author{
Ondřej Bábek ${ }^{1}$, Ondřej Vodehnal', Martin Faměra', Aleš Tomica ${ }^{2}$ \\ ${ }^{1}$ Katedra geologie PřF UP, Tř. Svobody 26, 77900 Olomouc; e-mail: babek@prfnw.upol.cz \\ 2Česká speleologická společnost, ZO 7-03 "Javoríčko"
}

(24-21 Jevíčko)

Key words: multielectrode resistivity surveying; karstification; tectonic structure; cave corridors, Moravo-Silesian Zone

\begin{abstract}
This paper investigates the scope and applicability of multielectrode resistivity surveying in the study of buried karst structures. Six resistivity sections, 62 to $117 \mathrm{~m}$ long, were measured above the well-documented cave system "Za hájovnou" in the Javoŕićko Karst, Bohemian Massif. Three domains of distinct resistivity values (27.6 to 210 $\Omega \cdot m ; \sim 210$ to $\sim 1300 \Omega \cdot m ; \sim 1300$ to $26112 \Omega \cdot m$ ) were interpreted as clays and silts, carbonate-rich karstified zones, and massive carbonate, respectively. Most of the geophysically documented karstification manifests itself in planar zones of karstified carbonate, partly filled with fine-grained siliciclastics, which coincide with several cave corridors in plan view. Orientation of the karstified zones corresponds to the NNE-SSW trending axial plane cleavage and ESE-WNW trending fractures and faults in the underlying rocks. The resistivity surveying proves to be an excellent method for mapping of shallow cave structures.
\end{abstract}

\section{Úvod}

Mělké odporové profilování si získává stále větší oblibu v aplikovaném geologickém výzkumu (inženýrská geologie, geoarcheologie, geomorfologie) díky relativně dobré dostupnosti, rychlé akvizici a poměrně jednoduchému zpracování dat (Lee et al. 2008, Sass et al. 2008, Van Den Eeckahut et al. 2007). Odporové profilování je založeno na měření měrného odporu (resistivita, $\rho[\Omega \cdot \mathrm{m}]$ ) podloží, který je funkcí minerálního složení, struktury hornin, obsahu a salinity vody $\mathrm{v}$ horninách a dalších parametrů (Musset - Aftab Khan 2000). Multielektrodové odporové profilování využívá k měření resistivity většího počtu elektrod (zpravidla několik desítek či prvních stovek) uspořádaných $\mathrm{v}$ linii nebo $\mathrm{v}$ pravidelné síti nad zkoumaným objektem. Výsledkem měření a následného matematického zpracování je inverzní 2D nebo 3D model resistivity, ve kterém lze rozhraní domén s různou resistivitou interpretovat jako rozhraní horninových celků. Mělce pohřbené povrchové a podpovrchové krasové jevy (závrty, zasucené komíny, jeskynní koridory) jsou př́kladem rozhraní mezi vysoce odporovými karbonáty $\left(\rho: 50-10^{7} \Omega \cdot \mathrm{m}\right.$, typicky $\left.>10^{3} \Omega \cdot \mathrm{m}\right)$ a jejich siliciklastickým pokryvem/ výplní s řádově nižšími hodnotami ( $\rho: 1-10^{2} \Omega \cdot m$ pro jíly). Krasové jevy tak teoreticky představují velmi vhodné cíle pro odporové profilování. V tomto příspěvku uvádíme výsledky odporového profilování okolí jeskyně „Za hájovnou“ v severní části Javoříčského krasu. Cílem práce je ověřit praktickou aplikaci této geofyzikální metody pro krasovou geomorfologii a potenciální speleologické prolongační práce.
Geologie a geomorfologie studované oblasti

Jeskyně "Za hájovnou“ (souřadnice vchodu: $49^{\circ} 40^{\prime} 27.141^{\prime \prime} \mathrm{N}, 16^{\circ} 55^{`} 0.812^{“} \mathrm{E}$; obr. 1) leží na jižním

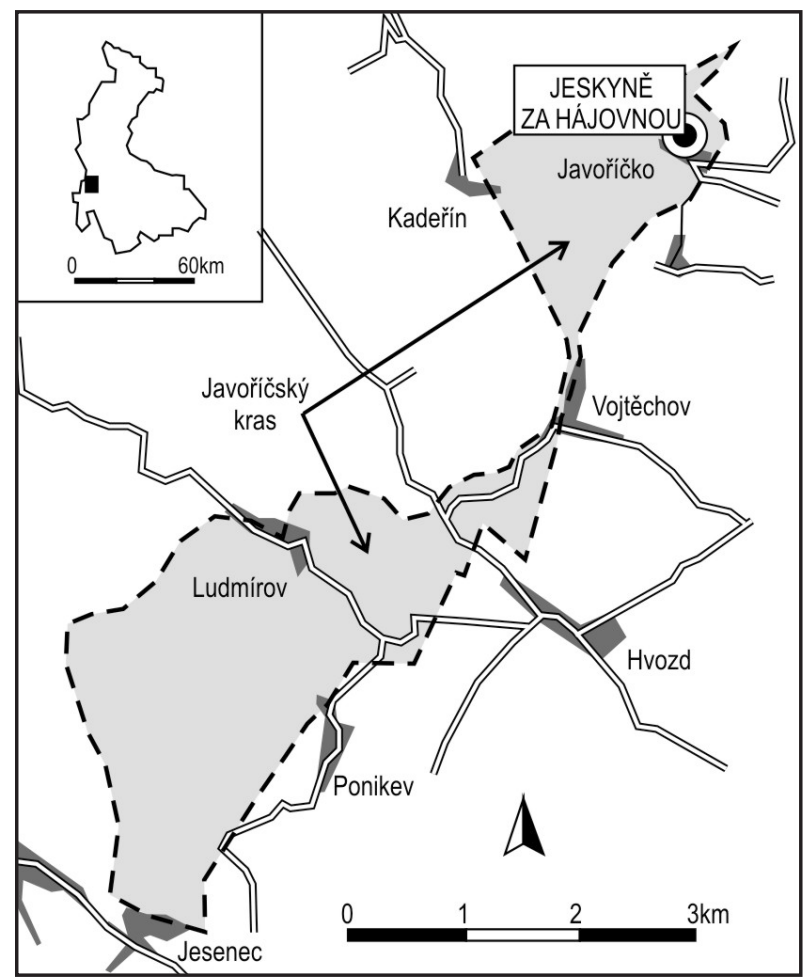

Obr. 1: Situační schéma Javoříčského krasu a jeskyně Za hájovnou a její pozice v Olomouckém kraji. Upraveno podle Kadlčíková (2005).

Fig. 1: The simplified map of the Javoríčco Karst and the Za hájovnou Cave and its position in the Olomouc region. Modified after Kadlč́ková (2005). 


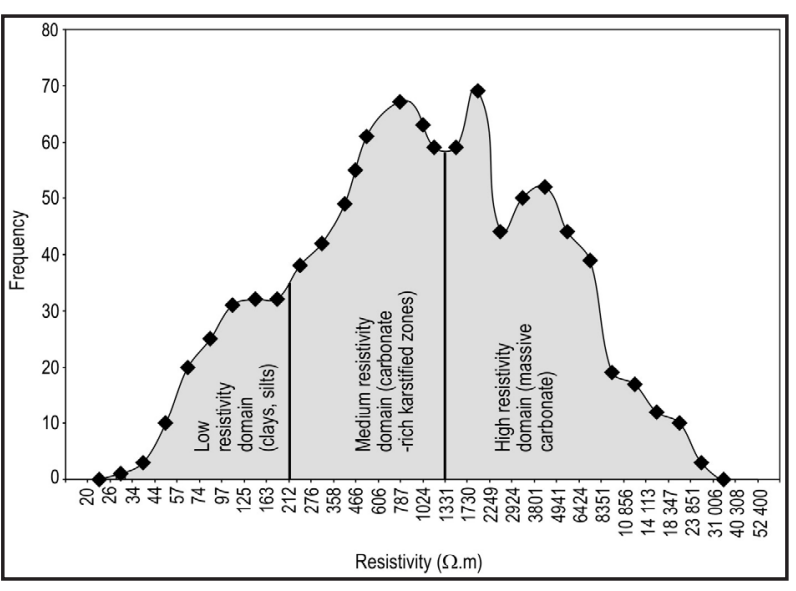

Obr. 2: Histogram hodnot měrného odporu z inverzních modelů na 5 profilech (profil 2 až 6; celkem 954 bodů). Maxima četnosti jsou interpretována jako tři základní litologické domény (viz text). Fig. 2: Frequency distribution of resistivity data from inversion models at 5 sections (section 2 to $6 ; 954$ points). Frequency peaks indicate the three inferred basic lithological domains (see text).

svahu vrchu „Brablenec“, při sz. okraji obce Javoříčko v severní části Javoříčského krasu (Panoš 1955), tvořeného silně zkrasovělými devonskými a spodnokarbonskými vápenci. Portál jeskyně leží v nadmořské výšce 385 m; její celková délka je $194 \mathrm{~m}$ a maximální převýšení $74 \mathrm{~m}$ (Tomica 2001). Jeskyně, která je označována za paleoponor potoka Javoříčka (Crha 1989), je vyplněna svahovými a fluviálními sedimenty s hojnými relikty savčí fauny (Musil 2005). Maximální stáří jeskynní výplně bylo stanoveno biostratigraficky do interglaciálu holstein (MIS 11) a magnetostratigraficky na rozhraní Brunhes/Matuyama (790 ka; MIS 19, Musil 2005). Stáŕí krasovění není stanoveno. Nepř́mými indikátory krasovění jsou datované spodnobadenské výplně krasových kapes u nedaleké Mladče, zatímco v nedaleké severní části Moravského krasu krasovění probíhalo od střední části křídy až do recentu (cf. Kadlec et al. 2001).

\section{Metody}

$\mathrm{V}$ rámci této práce bylo proměřeno celkem šest $2 \mathrm{D}$ profilů o jednotkové délce 62 až $117 \mathrm{~m}$ s rozestupem elektrod 2 nebo $3 \mathrm{~m}$ za použití automatického geoelektrického systému ARES (GF Instruments, s. r. o.). Měření probíhalo s maximálním roztažením 32 elektrod v uspořádání Wenner-Schlumberger a délkou impulsu $0,5 \mathrm{~s}$ a zprůměrováním dat (stacking) ze 4 měření v každém bodě; maximální hloubkový dosah inverzního modelu je cca $18 \mathrm{~m}$ pod povrchem. Data byla zpracována pomocí software RES2DINV (Geotomo Software).

\section{Výsledky odporového profilování}

Hodnoty měrného odporu z inverzních modelů resistivity vygenerovaných programem RES2DINV se pohybují v rozsahu $27,6 \Omega \cdot \mathrm{m}$ až $26112 \Omega \cdot \mathrm{m}$. Všechny

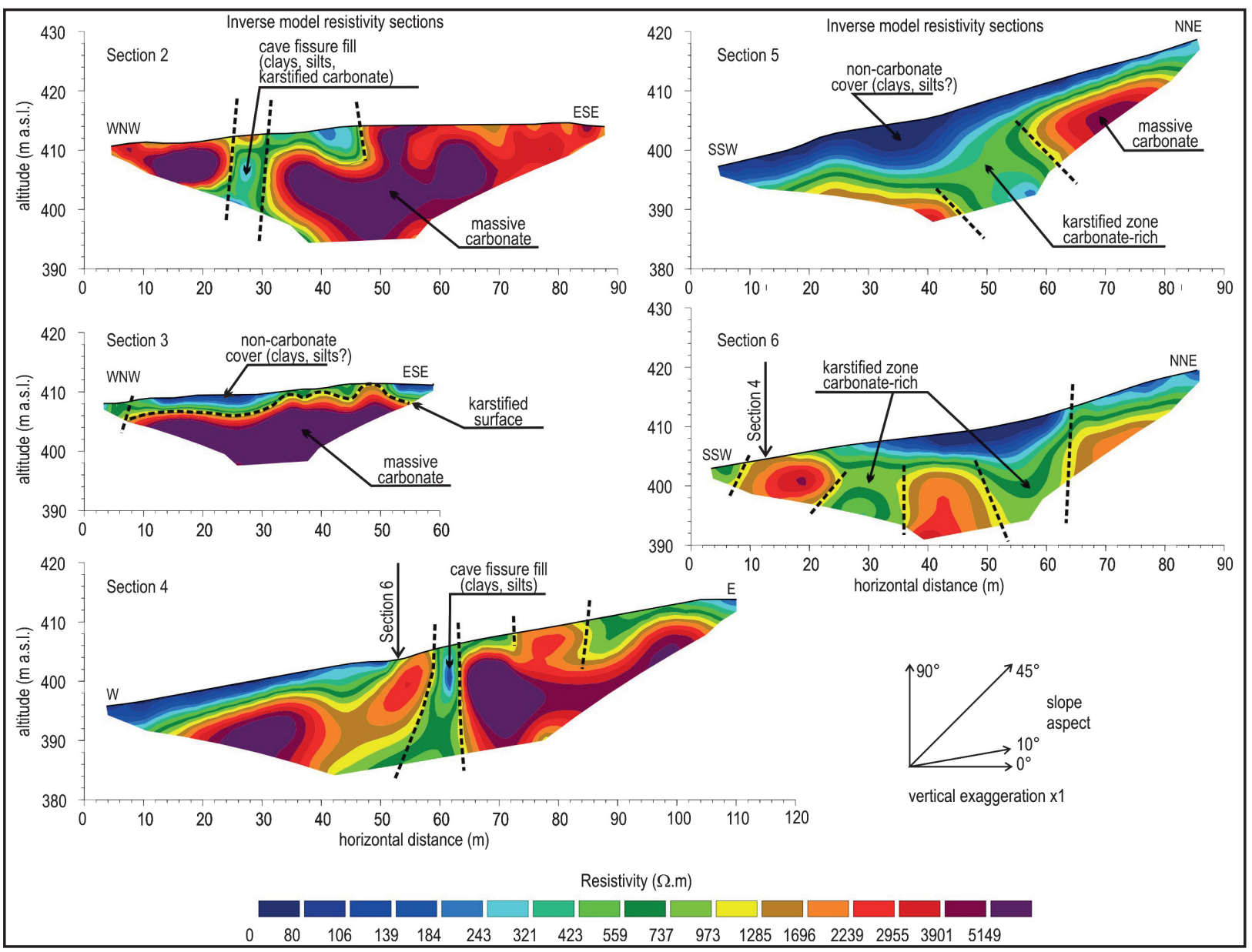

Obr. 3: Inverzní modely resistivity na profilech 2 až 6 a interpretace litologie.

Fig. 3: Inversion models of resistivity at sections 2 to 6 and interpretation of lithology and structure. 
profily vykazují poměrně jednoduchou distribuci hodnot resistivity se třemi hlavními doménami (obr. 2). Převážně spodní část profilů tvoří doména s nejvyššími hodnotami měrného odporu (více než $~ 1300 \Omega \cdot m$ ), která může místy vystupovat až k povrchu (např. profil 2, obr. 3). Tuto doménu můžeme interpretovat jako masivní vápence tzv. ekvivalentů macošského souvrství (stř.-sv. devon), které zde byly vymapovány Chlupáčem a Svobodou (1963) a Crhou (1989) a které jsou odkryty na řadě drobných výchozů v okolí jeskyně.

Svrchní část profilů naopak tvoří doména s nejnižšími hodnotami resistivity $(27,6$ až $~ 210 \Omega \cdot m)$, která má na všech profilech tvar nepravidelných čoček o maximální mocnosti $\sim 9 \mathrm{~m}$ a je často oddělena od podložní vysokoodporové domény úzkou přechodnou zónou s velmi prudkým gradientem měrného odporu (profily 3, 4, 5, obr. 3). Materiál s velmi podobnou odporovou charakteristikou můžeme sledovat i v úzkých (3-6 m) subvertikálních zónách sestupujících do hloubky, které jsou patrné na profilech 2 a 4. Tyto domény s poměrně vysokou vodivostí (nízkou resistivitou) můžeme interpretovat jako svahový pokryv a sedimentární výplně drobných krasových kapes a krasových komínů, tvořené nezpevněnými, jemnozrnnými siliciklastickými sedimenty (jíly, silty, písky) stáŕí kvartér až ?miocén (cf. Panoš et al. 1998, Musil 2005).

Třetí doménu se středně vysokými hodnotami měrného odporu ( 210 až $\sim 1300 \Omega \cdot \mathrm{m})$ můžeme vysledovat při povrchu profilů 2 a 4 a v širších (10-20 m) subvertikálních zónách na profilech $4,5 \mathrm{a} 6$. Tyto domény se stále poměrně vysokou resistivitou lze považovat za zvětralou a zkrasovělou povrchovou vrstvu vápencového masivu a zkrasovělé subvertikální struktury (komíny, puklinové zóny).

\section{Směry a geneze geofyzikálně ověřených krasových struktur}

Výsledky geofyzikálního měření je možné dobře korelovat s průběhem hlavních chodeb systému jeskyně Za hájovnou (obr. 4). Úzké subvertikální nízkoodporové zóny na profilech $2(22-28 \mathrm{~m}), 3(0-3 \mathrm{~m})$ a $4(65-70 \mathrm{~m})$ na sebe zřetelně navazují v ploše, která na povrchu probíhá ve směru SSV-JJZ a uklání se $\mathrm{k}$ ZSZ pod úhlem cca $85^{\circ}$. Tato plocha patrně reprezentuje výplň jeskynního komínu, který se v půdorysu kryje s Narozeninovou chodbou jeskyně Za hájovnou. Komín Narozeninové chodby tak evidentně vystupuje až k povrchu a ve shodě s dostupnými mapami jeskynních koridorů potvrzuje propastovitý charakter celého systému. Naproti tomu paralelní chodba Velikonoční jeskyně nebyla zachycena ani na jednom z profilů 1, 2 a 3, které půdorys této chodby protínají zhruba v kolmém směru. Rovněž profil 4 nenaznačuje směrné pokračování Velikonoční jeskyně dále k SSV.

Široké subvertikální zóny se středními hodnotami resistivity zachycené na profilech 5 a 6 na sebe rovněž navazují a vytyčují tak plochy, která mají na povrchu směr-

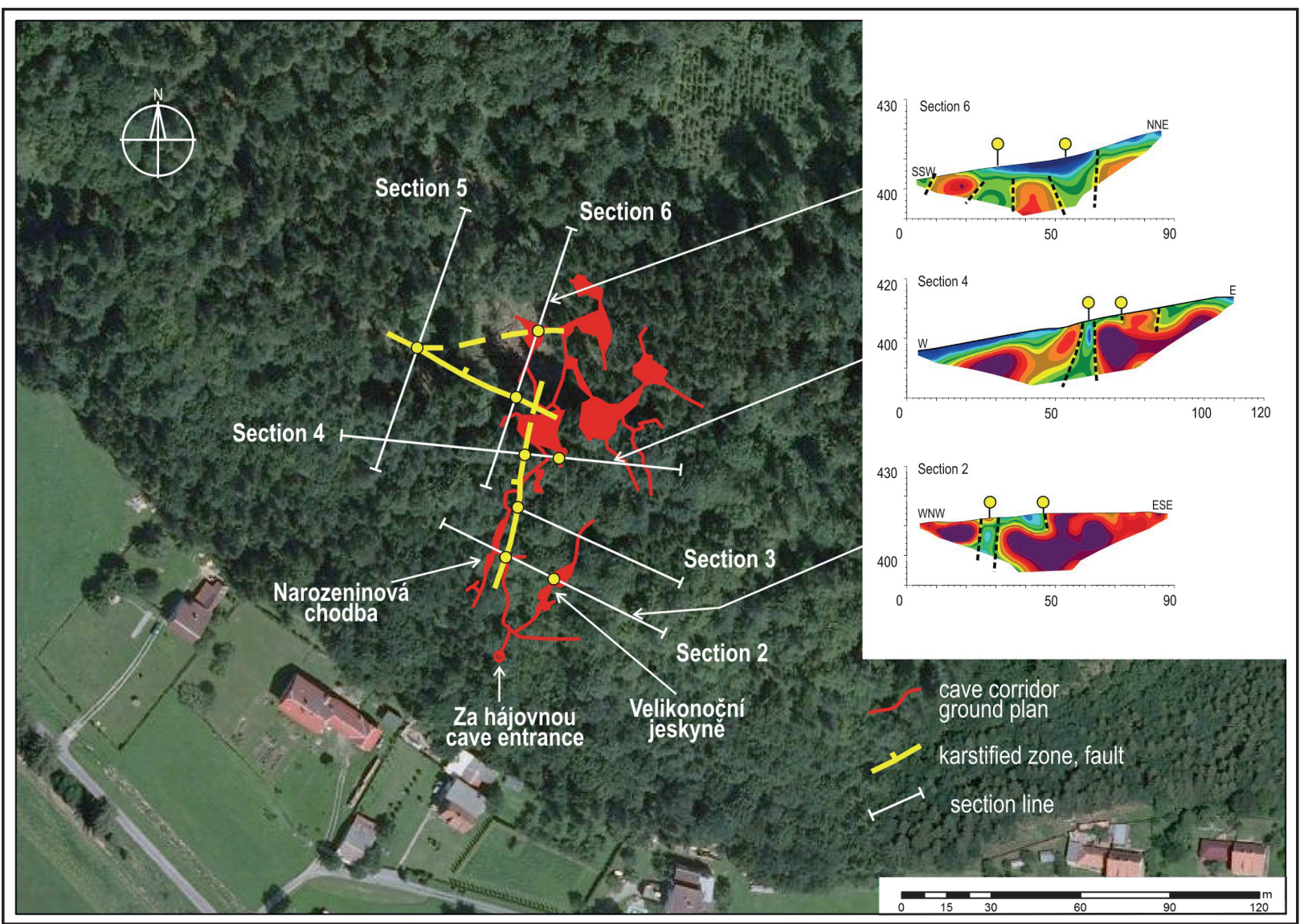

Obr. 4: Interpretace výsledků odporového profilování: povrchový průběh hlavních zón krasovění v nadloží jeskyně Za hájovnou na lokalitě Brablenec. Ortofotomapa převzata z Geoportálu Cenia.

Fig. 4: Interpretation of resistivity surveying results: surface projection of the major karstified structures compared to the ground plan of the Za hájovnou Cave. The orthophotomap adopted from Geoportal Cenia. 
ný průběh VJV-ZSZ a přibližně V-Z s úklonem zhruba $70^{\circ} \mathrm{k}$ S. Posledně zmíněná linie se projevuje morfologicky jako mírný svahový stupeň a v jejím pokračování cca $100 \mathrm{~m}$ zjz. od profilu 5 se nachází vstupní portál říční jeskyně „Habřri“. Situace na na profilech 4 a 6 poukazuje na poměrně komplikovaný průběh podpovrchových krasových struktur v hloubkách $\sim 10$ až 20 m a možné křížení jeskynních chodeb směrů VJV-ZSZ a SSV-JJZ (obr. 4). Prostorová orientace geofyzikálně vymapovaných krasových struktur tedy může naznačovat, že jeskynní systémy „Za hájovnou“ a „Habří jsou vzájemně propojeny.

Geofyzikálně ověřený směr Narozeninové chodby SSV-JJZ je převažujícím směrem krasových koridorů v masivu Brablence včetně vstupní chodby paleoponorové jeskyně Habří (Kadlčíková 2005) a vstupní chodby a koridorů Velikonoční jeskyně a Plakátův sen v jeskyni Za hájovnou (Tomica 2001). V masivu Špraňku jsou v tomto směru vyvinuty rozsáhlé koridory Vojtěchovské chodby, Babské jeskyně, Panenské jeskyně, Spojovací chodby a dalších koridorů Javoříčských jeskyní. Krasovění těchto chodeb je predisponováno regionálně významnou penetrativní foliací (osní kliváží) vápenců konicko-mladečského paleozoika o přednostním směru SSV-JJZ a úklonu cca $80^{\circ} \mathrm{k}$ ZSZ (Kadlč́́ková 2005, Bábek et al. 2006).

Směr geofyzikální zóny VJV-ZSZ z profilů 5 a 6 odpovídá přednostnímu směru přičných zlomů a puklinových zón v konicko-mladečském krasu, na kterých je vyvinuta řada jeskynních koridorů Javoříčské jeskyně (Kadlčíková 2005). V širším regionálním rámci tento směr odpovídá průběhu nectavského a olomoucko-holešovského zlomu a okrajového sudetského zlomu s recentní seismogenní aktivitou (Špaček et al. 2011). Případný směr V-Z druhé geofyzikální zóny (profily 5 a 6) patrně není jednoznačně predisponován tektonicky, protože křehké tektonické struktury tohoto směru jsou v konicko-mladečském paleozoiku extrémně vzácné (Kadlčíková 2005). Pro podrobnější vysvětlení orientace krasových struktur pod povrchem je nutné zahustit sít geofyzikálních profilů a nebo provést měření $3 \mathrm{D}$ odporové tomografie.

\section{Závěry}

Výsledky měření potvrzují, že multielektrodové odporové profilování je mimořádně vhodnou metodou k mělkému průzkumu krasu s velmi vysokou nadějí na úspěšné vymapování podpovrchových krasových struktur. Vhodnou konfigurací sítě $2 \mathrm{D}$ profilů při zohlednění tektonické stavby území (pukliny, foliace, vrstevnatosti) lze vymapovat směry a úklony hlavních krasových struktur a získat nezávislá data pro tektonickou analýzu území.

\section{Poděkování}

Tento výzkum byl financován z prostředků projektu GAČR P210/12/0573. Dékujeme dr. Josefu Havírovi (Brno) za konstruktivní recenzi rukopisu.

\section{Literatura}

Bábek, O. - Tomek, Č. - Melichar, R. - Kalvoda, J. - Otava, J. (2006): Structure of unmetamorphosed Variscan tectonic units of the southern Moravo-Silesian Massif: a review. - Neues Jahrbuch für Geologie und Paläontologie, Abhandlungen, 239, 37-75.

Crha, J. et al. (1989): Souhrnná závěrečná zpráva vyhledávacího průzkumu (1.-4. fáze). Ponikev-Vojtěchov, arch. sp. UNIGEO, Brno.

Chlupáč, I. - Svoboda, J. (1963): Geologické poměry konicko-mladečského devonu na Drahanské vrchovině. - Sborník Ústředního ústavu geologického, 28, 347-418.

Kadlč́́ková, J. (2005): Geomorfologická charakteristika a korelace endokrasu a exokrasu v okolí Javořička s využitím metody GIS, Javoříčský kras, konicko-mladečský pruh. - MS, diplomová práce PřF UP Olomouc, 73-76.

Kadlec, J. et al. (2001): Cenozoic history of the Moravian karst (northern segment): Cave sediments and karst morphology. - Acta Musei Moraviae, Scientiae geologicae, 86, 111-160.

Lee, C.-C. - Yang, C.-H. - Liu, H.-C. - Wen, K.-L. - Wang, Z.-B. - Chen, Y.-J. (2008): A study of the hydrogeological environment of the lishan landslide area using resistivity image profiling and borehole data. - Engineering Geology, 98, 115-125.

Musil, R. (2005): Jeskyně Za hájovnou, výjimečná lokalita Javořičský kras, Morava. - Př́rodovědné studie Muzea Prostějovska, $8,11-39$.

Mussett, A. E. - Khan, M. A. (2000): Looking into the Earth, An introduction to geological geophysics. - Cambridge University Press. Panoš, V. et al. (1998): Výskyt mořského spodního badenu jižně od Bouzova. - Zprávy o geologických výzkumech v roce 1997, 69-70. Panoš, V. (1955): Jeskyně severomoravského krasu. - Státní tělovýchovné nakladatelství Praha. Vysvětlivky k obrázkům a tabulce.

Sass, O. - Bell, R. - Glade, T. (2008): Comparison of GPR, 2D-resistivity and traditional techniques for the subsurface exploration of the Öschingen landslide, Swabian Alb (Germany). - Geomorphology, 93, 89-103.

Špaček, P. - Zacherle, P. - Sýkorová, Z. - Pazdírková, J. (2011): Microseismic multiplets in the northeastern Bohemian Massif. Zeitschrift für Geologische Wissenschaften, 39, 5/6, 367-386.

Tomica, A. (2001): Zpráva o nových objevech v lokalitě „Za hájovnou“. - Archiv AOPK ČR, oddělení ochrany jeskyní, 45-46. Praha. Van Den Eeckhaut, M. - Verstraeten, G. - Poesen, J. (2007): Morphology and internal structure of a dormant landslide in a hilly area: The Collinabos landslide (Belgium), Geomorphology, 89, 258-273. 